\title{
Post-anthesis accumulation and remobilization of dry matter, nitrogen and phosphorus in durum wheat as affected by soil type
}

\author{
Alessandro Masoni ${ }^{a}$,*, Laura Ercoli $^{\text {b }}$, Marco Mariotti ${ }^{a}$, Iduna Arduini ${ }^{a}$ \\ a Dipartimento di Agronomia e Gestione dell'Agroecosistema, via S. Michele degli Scalzi 2, 56125 Pisa, Italy \\ b Scuola Superiore Sant'Anna, Piazza Martiri della Libertà 33, 56127 Pisa, Italy \\ Received 5 September 2005; received in revised form 4 September 2006; accepted 15 September 2006
}

\begin{abstract}
The objective of the research was to quantify the changes in the accumulation of dry matter and $\mathrm{N}$ and $\mathrm{P}$ content of four durum wheat (Triticum durum Desf.) varieties grown on two soil types (sandy-loam and clay-loam), differing for texture, nitrogen content and water holding capacity. Plants were grown in containers and were rainfed until anthesis; irrigation was performed during grain filling to avoid water stress. The difference in total vegetative weight and nitrogen and phosphorus content of plants between anthesis and maturity was used to indirectly estimate the relative contribution of pre-anthesis assimilation and remobilization to grain yield. The behaviour of the four varieties was similar as they ranked in the same order for pre-anthesis and post-anthesis dry matter accumulation and grain yield and differences in soil characteristics induced similar changes in dry matter, $\mathrm{N}$ and $\mathrm{P}$ accumulation and remobilization. Soil type greatly affected the patterns of dry matter, $\mathrm{N}$ and $\mathrm{P}$ accumulation and remobilization. Plants grown on clay-loam soil had higher dry weight and $\mathrm{N}$ and $\mathrm{P}$ content both at anthesis and at maturity and higher grain yield at maturity, compared to plants grown on sandy-loam soil and the remobilization of dry matter, $\mathrm{N}$ and $\mathrm{P}$ were 75,140 and $55 \%$ higher. Most of the grain carbohydrates originated from photosynthates produced during grain fill, as the contribution of remobilization of dry matter to grain yield did not reach $30 \%$, while most of the grain $\mathrm{N}$ and $\mathrm{P}$ originated from the remobilization of $\mathrm{N}$ and $\mathrm{P}$ accumulated prior to anthesis as remobilization of $\mathrm{N}$ accounted for $73-82 \%$ of grain $\mathrm{N}$ content and remobilization of $\mathrm{P}$ accounted for $56-63 \%$ of grain $\mathrm{P}$ content.
\end{abstract}

(C) 2006 Elsevier B.V. All rights reserved.

Keywords: Accumulation; Dry matter; Durum wheat; Grain filling; Nitrogen; Phosphorus; Remobilization

\section{Introduction}

In cereals, the supply of assimilate to grain originates from current assimilation transferred directly to kernels and from the remobilization of assimilates stored temporarily in vegetative plant parts (Austin et al., 1980; Gebbing et al., 1999; Santiveri et al., 2004). Thus, reserves deposited in vegetative plant parts before anthesis may buffer grain yield against conditions adverse to current assimilation during the grain filling period. Temporary carbon storage in the vegetative parts occurs in the form of watersoluble carbohydrates (WSC) such as glucose, fructose, sucrose and starch, but the main reserve is fructan, whereas temporary nitrogen storage occurs in the form of amino acids and proteins (Schnyder, 1993; Przulj and Momcilovic, 2001).

\footnotetext{
* Corresponding author. Tel.: +39050 599217; fax: +39050 540633 .

E-mail address: amasoni@agr.unipi.it (A. Masoni).
}

Growing conditions from emergence to anthesis determine the effective stem reserve storage. Total stem water-soluble carbohydrates in wheat at anthesis were shown to vary greatly in different experiments, from 50 to $350 \mathrm{~g} \mathrm{~kg}^{-1}$ dry mass, as reported by Kiniry (1993). Also N content at anthesis varies among genotypes, yet genotypic variation for total $\mathrm{N}$ content at anthesis was associated primarily with variations in dry matter (Austin et al., 1977; Banziger et al., 1994). After anthesis, plants continue both growth and $\mathrm{N}$-assimilation, and significant quantities of $\mathrm{N}$ can be assimilated during grain filling (Austin et al., 1977; Cox et al., 1985). Under optimal growing conditions, assimilation and storage of assimilates is high, while when carbon assimilation is reduced by stress, storage is reduced (Davidson and Chevalier, 1992; Blum, 1998).

Large variability in the contribution of assimilates stored prior to anthesis to grain yield has been reported in wheat, and the estimated proportion of yield provided by remobilization of pre-anthesis dry matter ranged from 7 to $57 \%$ (Gallangher et al., 1976; Austin et al., 1977; Bidinger et al., 1977; Ehdaie and 
Waines, 2001). The remobilization of previous assimilated $\mathrm{N}$ accounted for 51-91\% of grain N content (Cox et al., 1985; Van Sanford and MacKown, 1987; Papakosta and Gagianas, 1991). Most of this variability can be attributed to differences in climate, soil type effects, genotypes, and crop management. Environmental conditions during the pre- and post-anthesis periods are likely to have different effects on dry matter and $\mathrm{N}$ accumulation. Under stress conditions, Palta et al. (1994) estimated that stored $\mathrm{C}$ and $\mathrm{N}$ contributed for 64 and $81 \%$ to total grain $\mathrm{C}$ and N, respectively. Van Herwaarden et al. (1998) showed that under dry field conditions, the apparent contribution of stored assimilates could be $75-100 \%$ of grain yield, as compared with $37-39 \%$ under high rainfall conditions.

Phosphorus uptake and translocation during grain filling in wheat has received much less attention. The amount of $\mathrm{P}$ in the grain derived from translocation ranged from 11 to $100 \%$, according to $\mathrm{P}$ availability, climate, and genotypes (Batten et al., 1986; Papakosta, 1994).

Some of the variability of data in literature is however due to the methodologies used for measuring remobilization. Most investigations dealing with reserve contributions to grain filling have made estimates applying growth analysis methodology, which determines the mobilization of reserve material as the net loss of dry matter in the vegetative above-ground plant parts between anthesis and grain maturity. However, this procedure has been criticized, since respiratory losses involved with the maintenance and redistribution of reserve photosynthate are not considered, the role of roots as a potential source of pre-anthesis $\mathrm{C}$ is often ignored and the shedding of dead leaves that occur during grain filling may determine an overestimate of mobilization (Bidinger et al., 1977; Kiniry, 1993; Gebbing et al., 1998; Przulj and Momcilovic, 2001).

Other researches have estimated the contribution of preanthesis reserves to grain labelling photosynthates and following the fate of the label (Bell and Incoll, 1990; Gent, 1994). Since quantification of the reserve contribution requires the labelling of entire plants or canopies, such experiments have been small in number and few have been conducted in field conditions. However, where growth analysis was combined with ${ }^{14} \mathrm{C}$ pulselabelling, it was estimated that data coming from growth analysis studies are likely to have overestimated the true contribution from pre-anthesis assimilation (Austin et al., 1977; Gebbing et al., 1998, 1999).

The objectives of this research were to examine the accumulation of dry matter, nitrogen and phosphorus during the vegetative and reproductive periods and the contribution of pre-anthesis assimilates to the grain yield of durum wheat (Triticum durum Desf.) grown on two soil types differing for texture, nitrogen content and water availability.

\section{Materials and methods}

The experiment was carried out in 1999-2000 and 2000-2001 at the Department of Agronomy and Agroecosystem Management of the University of Pisa in central Italy $\left(40^{\circ} 40^{\prime} \mathrm{N}, 10^{\circ} 19^{\prime} \mathrm{E}\right.$ and $1 \mathrm{~m}$ above sea level). The climate is cold, humid Mediterranean with mean annual maximum and minimum daily air temperatures of 20.2 and $9.5^{\circ} \mathrm{C}$, respectively, and precipitation of $971 \mathrm{~mm}$, with $663 \mathrm{~mm}$ received during the wheat cycle that is from November through June (Moonen et al., 2001). In both years the maximum and minimum temperatures and rainfall were in line with the 120-year averages in both years.

In each year, treatments were two soil types, sandy-loam (SL) and clay-loam (CL), and four durum wheat varieties, Cirillo, Creso, Duilio and Grazia. The four durum wheat cultivars used are widely grown in Central Italy. Cirillo and Grazia are new high-yielding varieties, Creso is an old, medium-yielding stable variety, and Duilio is considered an intermediate type with respect to the ratio between grain yield and grain protein concentration. All varieties were released in Italy. The experiment was arranged in a randomized block design with three replications (containers). The research was carried out using 48 containers (24 for each sampling stage) of $100 \mathrm{~L}$ volume $\left(0.25 \mathrm{~m}^{2}\right.$ area and $0.4 \mathrm{~m}$ height). Containers were placed outdoors and arranged in three rows of 16 , spaced $10 \mathrm{~cm}$, and were embedded in vermiculite to smooth daily fluctuations in soil temperature. Containers were filled with two soils differing in textural properties, which were tamped to about original soil bulk density. Preplant soil samples were taken from containers to determine their physical and chemical properties. Field capacity and permanent wilting point were also determined for each soil type at 33 and $1500 \mathrm{kPa}$ soil water tension using the pressure chamber method. Soil properties are reported in Table 1.

The four durum wheat cultivars were sown on 17 November 1999 and 19 November 2000 at a rate of 400 seeds $\mathrm{m}^{-2}$ in rows spaced $15 \mathrm{~cm}$ apart. Fertilization consisted of $60 \mathrm{~kg} \mathrm{ha}^{-1}$ $\mathrm{N}$ as urea, $100 \mathrm{~kg} \mathrm{ha}^{-1} \mathrm{P}_{2} \mathrm{O}_{5}$ as triple super phosphate and $100 \mathrm{~kg} \mathrm{ha}^{-1} \mathrm{~K}_{2} \mathrm{O}$ as $\mathrm{K}_{2} \mathrm{SO}_{4}$ fertilizer applied preplanting, and $120 \mathrm{~kg} \mathrm{ha}^{-1} \mathrm{~N}$ as urea applied sidedress at stage 31 of the scale of Zadoks et al. (1974) on 1 March 2000 and 8 March 2001. Fertilizer rates were those conventionally applied in Tuscany to durum wheat. Irrigation was performed when necessary to avoid water stress that may occur in containers especially during grain filling. As a whole, two irrigations were applied between anthesis and maturity, utilizing a microirrigation system until field capacity was reached.

Measurements of crop growth were done at anthesis, stage 60 of the scale of Zadoks on 15 May 2000 and 11 May 2001,

Table 1

Physical and chemical properties of the two soils used in the experiment

\begin{tabular}{lcc}
\hline Character & \multicolumn{2}{l}{ Soil texture class } \\
\cline { 2 - 3 } & Sandy-loam $(\%)$ & Clay-loam $(\%)$ \\
\hline $\mathrm{Sand}(2.0>\varnothing>0.02)$ & 74.8 & 27.4 \\
$\mathrm{Silt}(0.02>\varnothing>0.002)$ & 18.6 & 37.3 \\
$\mathrm{Clay}(\varnothing<0.002)$ & 6.6 & 35.3 \\
$\mathrm{pH}$ & 7.2 & 7.5 \\
$\mathrm{CaCO}$ & 1.8 & 2.3 \\
$\mathrm{Nitrogen}($ Kjeldahl) & 1.0 & 1.2 \\
$\mathrm{P}_{2} \mathrm{O}_{5}($ Olsen$)$ & 1.2 & 3.5 \\
$\mathrm{~K}_{2} \mathrm{O}($ Dirks-Sheffer) & 1.4 & 8.6 \\
Organic matter $($ Walkley and Black) & 1.9 & 2.3 \\
Field capacity & 12.3 & 27.4 \\
Permanent wilting point & 5.3 & 16.3 \\
\hline
\end{tabular}


and at physiological maturity, stage 90 on 19 June 2000 and 20 June 2001. All plants in containers were cut at ground level and were separated into leaves, culms and spikes at anthesis and into leaves, culms, chaff and grain at maturity. Harvest index, number of spikes per unit area, mean kernel dry weight and number of kernels per spike were also measured at maturity. Roots were separated from the soil by washing with water until the roots were totally clean. For dry weight determination all plant parts were oven dried at $70^{\circ} \mathrm{C}$ to constant weight. Plant samples were analyzed for nitrogen (microKjeldahl) and phosphorus (ammonium-molybdophosphoric blue color method) concentrations and $\mathrm{N}$ and $\mathrm{P}$ contents were calculated by multiplying the $\mathrm{N}$ or $\mathrm{P}$ concentration by dry weight. Nitrogen and phosphorus harvest index were also calculated as: $(\mathrm{N}$ or $\mathrm{P}$ content of grain $/ \mathrm{N}$ or $\mathrm{P}$ content of aerial plant part) $\times 100$.

Moreover, the following parameters, related to dry matter and $\mathrm{N}$ and $\mathrm{P}$ accumulation and remobilization within the wheat plant during grain filling, were calculated:

1. Post-anthesis dry matter, $\mathrm{N}$ and $\mathrm{P}$ accumulation as the difference between dry matter, $\mathrm{N}$ or $\mathrm{P}$ content of the whole plant at anthesis and at physiological maturity.

2. Dry matter remobilization $(\mathrm{DMR})=$ dry matter of the whole plant at anthesis - dry matter of roots, leaves, culms and chaff at maturity.

3. Nitrogen remobilization $(\mathrm{NR})=\mathrm{N}$ content of the whole plant at anthesis $-\mathrm{N}$ content of roots, leaves, culms and chaff at maturity.

4. Phosphorus remobilization $(\mathrm{PR})=\mathrm{P}$ content of the whole plant at anthesis $-\mathrm{P}$ content of roots, leaves, culms and chaff at maturity.

5. Dry matter remobilization efficiency $=(D M R /$ dry matter of the whole plant at anthesis) $\times 100$.

6. Nitrogen remobilization efficiency $=(\mathrm{NR} / \mathrm{N}$ content of the whole plant at anthesis) $\times 100$.

7. Phosphorus remobilization efficiency $=(\mathrm{PR} / \mathrm{P}$ content of the whole plant at anthesis) $\times 100$.

8. Contribution of dry matter remobilized assimilates to grain $=(D M R /$ dry matter of grains at maturity $) \times 100$.

9. Contribution of remobilized nitrogen to grain $\mathrm{N}$ content $=(\mathrm{NR} / \mathrm{N}$ content of grains at maturity $) \times 100$.

10. Contribution of remobilized phosphorus to grain $\mathrm{P}$ content $=(\mathrm{PR} / \mathrm{P}$ content of grains at maturity $) \times 100$.

For the estimate of DR, NR and PR it was assumed that all of the dry matter and $\mathrm{N}$ lost from vegetative plant parts were remobilized to the developing grain, since losses of dry matter due to plant respiration and losses of $\mathrm{N}$ due to volatilization during grain filling were not determined.

Data were statistically treated by ANOVA, performed separately for each harvest in order to test the main effects of year, soil type and variety and their interactions. Because the main effect of year and its interactions were not significant a successive analysis of variance was carried out using years as replications. Duncan's multiple range test was used to separate the means when the ANOVA $F$-test indicated a significant effect of the treatment (Steel and Torrie, 1980).

\section{Results}

For all characters, the soil type $\times$ variety interaction effect was not significant; therefore, only variety and soil type mean effects are discussed in the paper.

\subsection{Dry matter}

At maturity grain yield, averaged over soil type, was higher in Grazia and Cirillo than in Creso (Table 2). Differences in grain yield among varieties depended on differences of the number of spikes per unit area and in the number of kernels per spike, while mean kernel weight was not affected $(41 \mathrm{mg})$. The lower grain yield of Creso was only associated to the lower number of kernels per spike, since this variety showed the highest number of spikes per unit area.

Averaged over varieties, grain yield was $519 \mathrm{~g} \mathrm{~m}^{-2}$ on clayloam soil and $217 \mathrm{~g} \mathrm{~m}^{-2}$ on sandy-loam soil. The higher grain yield of plants grown on the clay-loam soil depended exclusively on the higher number of kernels per spike, that increased over two-fold, while both mean kernel weight and number of spikes per unit area were unchanged (Table 2).

Genotypic differences in the dry weight of the other plant parts were low and reflected those of grain yield. At both stages, differences in dry weight of leaves and roots were not significant, and averaged over all treatments, dry weight of leaves was $212 \mathrm{~g} \mathrm{~m}^{-2}$ at anthesis and $170 \mathrm{~g} \mathrm{~m}^{-2}$ at maturity, and that of roots was 90 and $53 \mathrm{~g} \mathrm{~m}^{-2}$. The dry weight of culms was significantly lower for Duilio, compared to the other varieties (Table 3). Spike dry weight was higher for Cirillo and Grazia

Table 2

Grain yield, number of spikes and number of kernels per spike

\begin{tabular}{llll}
\hline Treatments & Grain yield $\left(\mathrm{g} \mathrm{m}^{-2}\right)$ & Spikes $\left(\mathrm{n} \mathrm{m}^{-2}\right)$ & Kernels per spike (n) \\
\hline Variety & & & \\
Cirillo & $381.2 \mathrm{a}$ & $419 \mathrm{~b}$ & $21.8 \mathrm{a}$ \\
Creso & $331.6 \mathrm{~b}$ & $462 \mathrm{a}$ & $17.4 \mathrm{c}$ \\
Duilio & $360.0 \mathrm{ab}$ & $427 \mathrm{~b}$ & $20.3 \mathrm{~b}$ \\
Grazia & $398.8 \mathrm{a}$ & $442 \mathrm{ab}$ & $22.5 \mathrm{a}$ \\
Soil type & & & \\
Sandy-loam & $216.8 \mathrm{~b}$ & $431 \mathrm{a}$ & $40.8 \mathrm{a}$ \\
Clay-loam & $519.0 \mathrm{a}$ & $434 \mathrm{a}$ & $41.5 \mathrm{a}$
\end{tabular}

Variety and soil type mean values. Within treatment variety and soil type, numbers followed by the same letter are not significantly different at $P \leq 0.05$.

Table 3

Dry weight of culms and spikes at anthesis and maturity

\begin{tabular}{|c|c|c|c|c|}
\hline \multirow[t]{3}{*}{ Variety } & \multicolumn{4}{|c|}{ Dry weight $\left(\mathrm{g} \mathrm{m}^{-2}\right)$} \\
\hline & \multicolumn{2}{|l|}{ Culms } & \multicolumn{2}{|l|}{ Spikes } \\
\hline & Anthesis & Maturity & Anthesis & Maturity \\
\hline Cirillo & $551.7 \mathrm{a}$ & $488.0 \mathrm{a}$ & $109.6 \mathrm{ab}$ & $547.3 \mathrm{ab}$ \\
\hline Creso & $532.4 \mathrm{a}$ & $456.0 \mathrm{ab}$ & $96.8 \mathrm{~b}$ & $489.0 \mathrm{c}$ \\
\hline Duilio & $478.2 \mathrm{~b}$ & $411.2 \mathrm{~b}$ & $97.4 \mathrm{~b}$ & $521.1 \mathrm{~b}$ \\
\hline Grazia & $544.2 \mathrm{a}$ & $464.4 \mathrm{ab}$ & $116.0 \mathrm{a}$ & $570.0 \mathrm{a}$ \\
\hline
\end{tabular}

Variety mean values. Within columns, numbers followed by the same letter are not significantly different at $P \leq 0.05$. 
Table 4

Harvest index of dry matter, nitrogen and phosphorus

\begin{tabular}{llll}
\hline Treatments & \multicolumn{2}{l}{ Harvest index $(\%)$} & \\
\cline { 2 - 4 } & Dry matter & Nitrogen & Phosphorus \\
\hline Variety & & $77.8 \mathrm{a}$ \\
Cirillo & $31.8 \mathrm{ab}$ & $62.6 \mathrm{ab}$ & $72.2 \mathrm{~b}$ \\
Creso & $29.5 \mathrm{~b}$ & $59.1 \mathrm{~b}$ & $75.0 \mathrm{a}$ \\
Duilio & $32.7 \mathrm{ab}$ & $60.2 \mathrm{~b}$ & $77.8 \mathrm{a}$ \\
Grazia & $33.1 \mathrm{a}$ & $64.5 \mathrm{a}$ & \\
Soil type & & & $64.3 \mathrm{~b}$ \\
Sandy-loam & $25.9 \mathrm{~b}$ & $52.5 \mathrm{~b}$ & $82.6 \mathrm{a}$ \\
Clay-loam & $35.2 \mathrm{a}$ & $66.4 \mathrm{a}$ & \\
\hline
\end{tabular}

Variety and soil type mean values. Within treatment variety and soil type, numbers followed by the same letter are not significantly different at $P \leq 0.05$.

than for Creso and Duilio at both stages (Table 3). The harvest index did not differ greatly among varieties and ranged from $33.1 \%$ of Grazia to $29.5 \%$ of Creso (Table 4 ).

Soil type markedly affected the dry weight of all plant parts except roots both at anthesis and at maturity stage. Averaged over genotypes, the higher values of all plant parts were recorded on clay-loam soil (Fig. 1). The dry weight of spikes and vegetative parts of plants grown on clay-loam soil were 81 and 58\% higher than that of plants grown on sandy-loam soil at anthesis and 101 and $49 \%$ higher at maturity. As a consequence, at maturity the
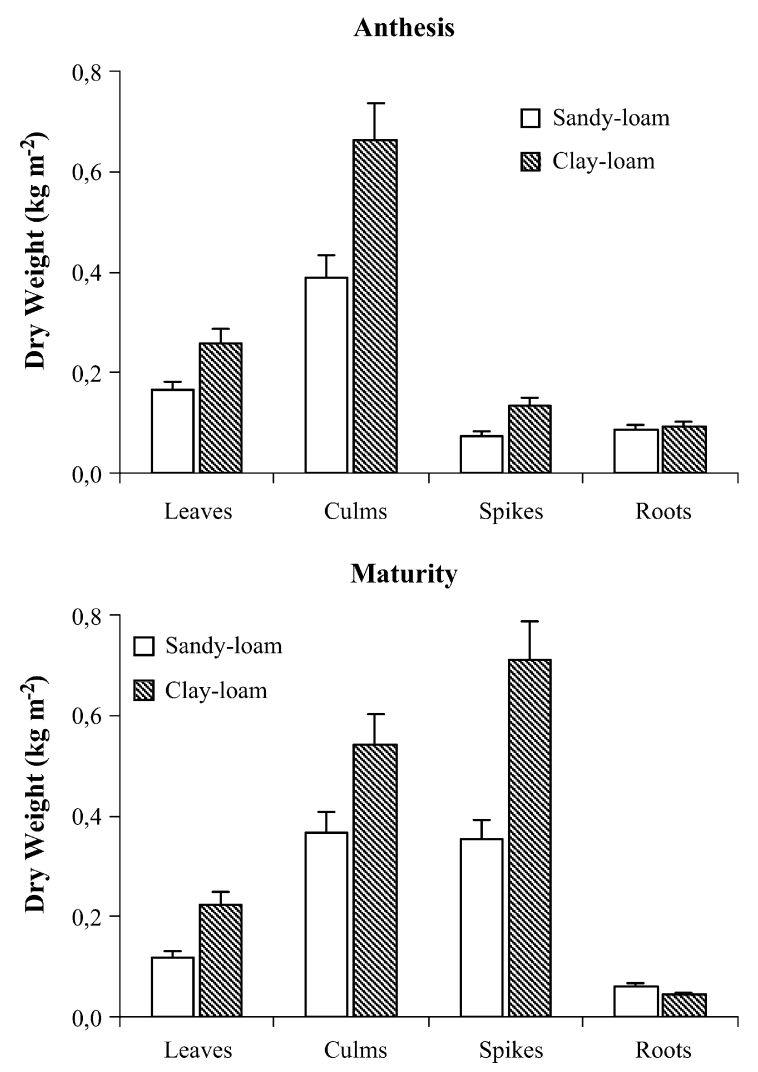

Fig. 1. Dry weight of leaves, culms, spikes, and roots at anthesis and at maturity. Soil type mean values. In this and in the following figures, vertical bars indicate standard error.
Table 5

Post-anthesis dry matter accumulation (DMA), dry matter remobilized into grain (DMR), dry matter remobilization efficiency (DMRE) and contribution of remobilization to grain yield (DMRC)

\begin{tabular}{llrrl}
\hline Treatments & DMA $\left(\mathrm{g} \mathrm{m}^{-2}\right)$ & DMR $\left(\mathrm{g} \mathrm{m}^{-2}\right)$ & DMRE (\%) & DMRC (\%) \\
\hline Variety & & & & \\
$\quad$ Cirillo & $297.4 \mathrm{a}$ & $83.8 \mathrm{~b}$ & $8.7 \mathrm{~b}$ & $22.0 \mathrm{c}$ \\
Creso & $233.8 \mathrm{~b}$ & $97.9 \mathrm{a}$ & $10.4 \mathrm{a}$ & $29.5 \mathrm{a}$ \\
Duilio & $278.8 \mathrm{ab}$ & $81.3 \mathrm{~b}$ & $9.4 \mathrm{~b}$ & $22.6 \mathrm{c}$ \\
Grazia & $295.8 \mathrm{a}$ & $103.0 \mathrm{a}$ & $10.6 \mathrm{a}$ & $25.8 \mathrm{~b}$ \\
Soil type & & & & \\
$\quad$ Sandy-loam & $182.4 \mathrm{~b}$ & $34.4 \mathrm{~b}$ & $4.8 \mathrm{~b}$ & $15.9 \mathrm{~b}$ \\
Clay-loam & $370.4 \mathrm{a}$ & $148.6 \mathrm{a}$ & $12.9 \mathrm{a}$ & $28.6 \mathrm{a}$ \\
\hline
\end{tabular}

Variety and soil type mean values. Within treatment variety and soil type, numbers followed by the same letter are not significantly different at $P \leq 0.05$.

harvest index of plants grown on clay-loam soil was $36 \%$ greater compared to plants grown on sandy-loam soil (Table 4).

From anthesis to maturity a decrease in dry matter was observed in leaves, culms and roots, whereas, owing to spikes growth, whole plant dry weight at maturity was $20-24 \%$ higher than at anthesis. The amount of post-anthesis accumulated dry matter differed among varieties: averaged over the two soils, accumulation was $6 \%$ higher in Cirillo and Grazia than in Duilio and $21 \%$ higher than in Creso (Table 5). Genotypic variation was also observed for dry matter translocation during grain filling and for efficiency of biomass remobilization, with Grazia and Creso exhibiting 22\% higher values than Cirillo and Duilio for the former and $16 \%$ for the latter. The contribution of mobilized dry matter to grain yield was higher than $22 \%$ and differed among varieties, with that of Creso being $14 \%$ higher than that of Grazia and 32\% higher than those of Cirillo and Duilio (Table 5). Post-anthesis accumulation of dry matter was 3.5 times higher than remobilization for Cirillo and Duilio and 2.9-2.5 higher for Grazia and Creso.

The effect of soil type was striking on both post-anthesis dry matter accumulation and remobilization (Table 5). Plants grown on clay-loam soil had a $103 \%$ higher dry matter accumulation compared to plants grown on sandy-loam soil and a $300 \%$ higher dry matter remobilization. Remobilization efficiency was also 200\% higher in clay-loam soil. As a result, the proportion of mobilized reserves to grain yield increased from $16 \%$ in sandy-loam soil to $29 \%$ in clay-loam soil. Post-anthesis accumulation of dry matter was higher than remobilization by over five fold in sandy-loam soil and by over two-fold in clay loam soil.

\subsection{Nitrogen}

At both stages, $\mathrm{N}$ concentration in all plant parts was not significantly different among varieties and soil types. Averaged over all treatments, the $\mathrm{N}$ concentration decreased from anthesis to maturity in leaves, culms and spikes, and it did not change in roots (Fig. 2).

Genotypic differences in nitrogen content of different plant parts were observed at both stages. At anthesis, varieties differed only for leaves and culms $\mathrm{N}$ content, in that values recorded for 


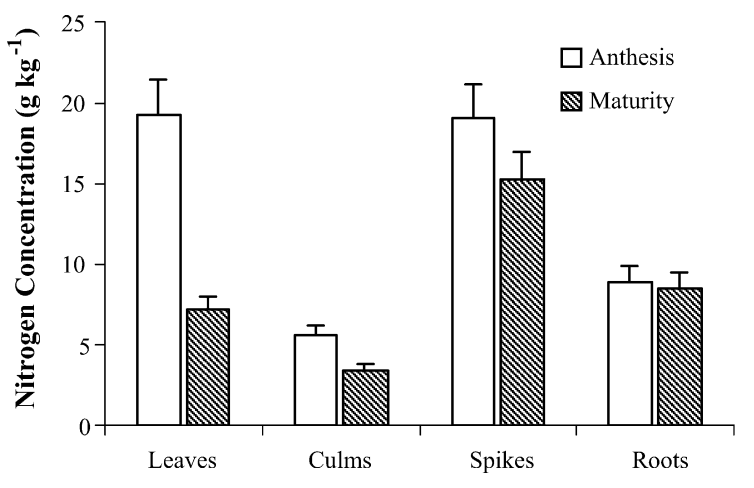

Fig. 2. Nitrogen concentration of leaves, culms, spikes, and roots at anthesis and at maturity.

Creso and Duilio were higher than those of Cirillo and Grazia (Fig. 3). At maturity, varieties showed differences in the nitrogen content of culms, spikes and grain. The $\mathrm{N}$ content of culms was higher in Creso than in the other varieties. In contrast, the variety Grazia showed the highest $\mathrm{N}$ content of spikes and grain (Fig. 3).

Soil type modified $\mathrm{N}$ content of wheat plants at both stages. The effect was statistically significant at anthesis for all plant parts except roots, and at maturity for leaves, spikes and grain, owing to the effect on dry matter yield (Fig. 4). As a consequence, at maturity $\mathrm{N}$ uptake of the whole plant was $66 \%$ higher on clay-loam soil compared to sandy-loam soil.
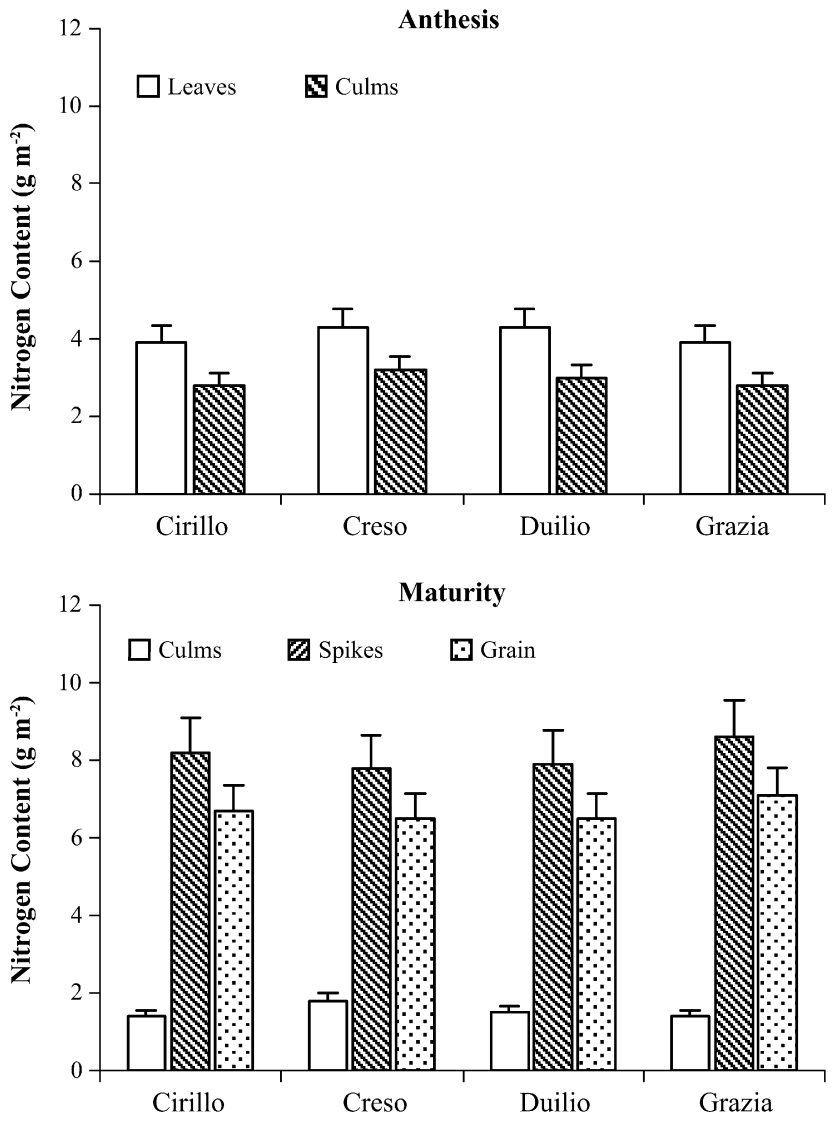

Fig. 3. Nitrogen content of leaves and culms at anthesis, and nitrogen content of culms, spikes, and grain at maturity. Variety mean values.

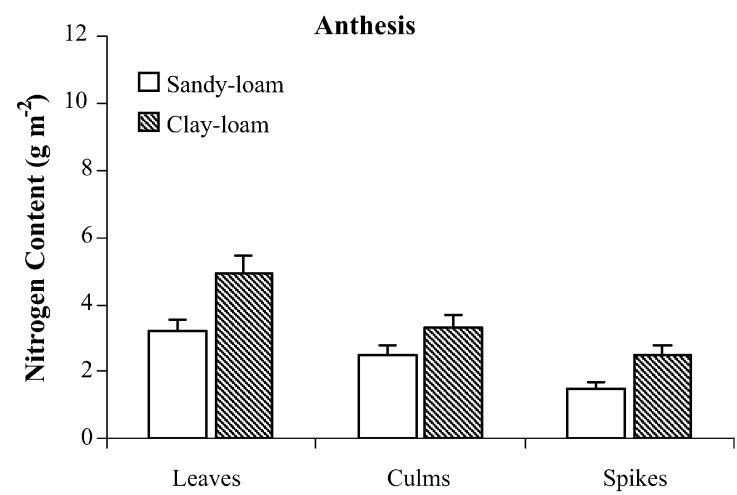

Maturity

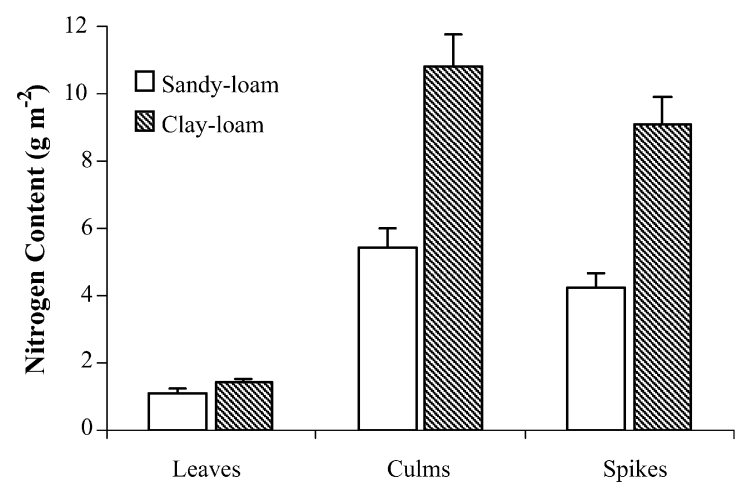

Fig. 4. Nitrogen content of leaves, culms, and spikes at anthesis, and nitrogen content of leaves, spikes, and grain at maturity. Soil type mean values.

The ability to accumulate $\mathrm{N}$ in grain was influenced by variety and soil type, as Grazia and Cirillo showed nitrogen harvest index 7\% higher than Creso and Duilio (Table 4) and plants grown on clay-loam soil had a $26 \%$ greater value (Table 4 ).

Most of $\mathrm{N}$ uptake occurred by anthesis and the proportion varied with soil type, but not with variety. Plants grown on sandyloam soil accumulated a higher proportion of $\mathrm{N}$ before anthesis (93\%), compared to plants grown on clay-loam soil (82\%).

Post-anthesis accumulation of $\mathrm{N}$ in the whole plant was evident in all cultivars and soil types, due to accumulation of $\mathrm{N}$ in spikes. Among varieties, during grain filling $\mathrm{N}$ accumulation ranked in the same order of dry matter accumulation (Table 6).

Table 6

Post-anthesis nitrogen accumulation (NA), nitrogen remobilized into grain (NR), nitrogen remobilization efficiency (NRE) and contribution of nitrogen remobilized to nitrogen content of grain (NRC)

\begin{tabular}{lllll}
\hline Treatments & NA $\left(\mathrm{g} \mathrm{m}^{-2}\right)$ & NR $\left(\mathrm{g} \mathrm{m}^{-2}\right)$ & NRE $(\%)$ & NRC (\%) \\
\hline Variety & & & & \\
$\quad$ Cirillo & $1.6 \mathrm{a}$ & $5.1 \mathrm{a}$ & $53.7 \mathrm{a}$ & $76.1 \mathrm{~b}$ \\
Creso & $1.2 \mathrm{~b}$ & $5.3 \mathrm{a}$ & $51.5 \mathrm{a}$ & $81.5 \mathrm{a}$ \\
Duilio & $1.2 \mathrm{~b}$ & $5.3 \mathrm{a}$ & $53.0 \mathrm{a}$ & $81.5 \mathrm{a}$ \\
Grazia & $1.9 \mathrm{a}$ & $5.2 \mathrm{a}$ & $54.2 \mathrm{a}$ & $73.2 \mathrm{~b}$ \\
Soil type & & & & \\
$\quad$ Sandy-loam & $0.6 \mathrm{~b}$ & $3.6 \mathrm{~b}$ & $45.6 \mathrm{~b}$ & $85.7 \mathrm{~b}$ \\
Clay-loam & $2.5 \mathrm{a}$ & $6.6 \mathrm{a}$ & $56.9 \mathrm{a}$ & $72.5 \mathrm{a}$ \\
\hline
\end{tabular}

Variety and soil type mean values. Within treatment variety and soil type, numbers followed by the same letter are not significantly different at $P \leq 0.05$. 
Averaged over soil type, Cirillo and Grazia accumulated more than Creso and Duilio (+75\%). The effect of soil type was also consistent: plants grown on clay-loam soil had a four-fold higher nitrogen accumulation. The mass of remobilized $\mathrm{N}$ and the $\mathrm{N}$ remobilization efficiency varied with soil type but not with varieties. On average, varieties remobilized $5.2 \mathrm{~g} \mathrm{~N} \mathrm{~m}^{-2}$ and the remobilization efficiency was $53 \%$. Plants grown on clay-loam soil remobilized a higher amount of $\mathrm{N}(+83 \%)$ than plants grown on sandy-loam soil, although the $\mathrm{N}$ remobilization efficiency increased only by $25 \%$. Consequently, the contribution of $\mathrm{N}$ remobilized to $\mathrm{N}$ content of grain was $12 \%$ higher in plants grown on sandy-loam soil and the proportion of $\mathrm{N}$ remobilized to $\mathrm{N}$ grain content was $9 \%$ higher for Creso and Duilio than for Cirillo and Grazia.

The remobilization of nitrogen was higher than postanthesis accumulation in all treatments. The ratio remobilization/accumulation did not vary among varieties, and $\mathrm{N}$ remobilization was three to four times higher than $\mathrm{N}$ accumulation for the four varieties, whereas, it was six-fold higher than $\mathrm{N}$ accumulation for plants grown on sandy-loam soil, and only 2.6 times higher for plants grown on clay-loam soil.

\subsection{Phosphorus}

Phosphorus concentration of all plant parts did not vary among varieties and soil types and decreased from anthesis to maturity. Phosphorus content of all plant parts did not vary among varieties and soil types, with the exception of $\mathrm{P}$ content of grain, that was $0.9 \mathrm{~g} \mathrm{~m}^{-2}$ in plants grown on sandyloam soil and $1.9 \mathrm{~g} \mathrm{~m}^{-2}$ in plants grown on clay-loam soil. From anthesis to maturity $\mathrm{P}$ content decreased in leaves and culms, did not change in roots and increased four-fold in spikes (Fig. 5).

The ability to accumulate $\mathrm{P}$ in grain was different among varieties, but the range in phosphorus harvest index was narrow, ranging from 72.2 to $77.8 \%$ (Table 4). Soil type greatly affected $\mathrm{P}$ harvest index that was $28 \%$ higher in plants grown on clayloam soil (Table 4).

From 68 to $75 \%$ of plant $\mathrm{P}$ recorded at maturity had been accumulated by anthesis. The proportion was not affected by variety and soil type.

Post-anthesis accumulation of whole plant $\mathrm{P}$, remobilized $\mathrm{P}$ from vegetative plant parts and $P$ remobilization efficiency did not vary substantially among varieties (Table 7). On average, varieties accumulated $0.5 \mathrm{~g} \mathrm{P} \mathrm{m}^{-2}$ and remobilized $0.8 \mathrm{~g} \mathrm{P} \mathrm{m}^{-2}$ during grain filling with a remobilization efficiency of about $60 \%$. The contribution of remobilized $\mathrm{P}$ to $\mathrm{P}$ grain content differed among varieties, as Creso and Duilio showed 6\% higher values than that of Cirillo and Grazia.

Soil type significantly affected the pattern of $\mathrm{P}$ accumulation and remobilization and $\mathrm{P}$ remobilization efficiency. Plants grown on clay-loam soil had a $75 \%$ greater post-anthesis $\mathrm{P}$ accumulation, a $140 \%$ greater $\mathrm{P}$ remobilization and a $55 \%$ greater $\mathrm{P}$ remobilization efficiency compared to plants grown on sandyloam soil. Also the contribution of $\mathrm{P}$ remobilization to $\mathrm{P}$ content of grain was higher in plants grown on clay-loam soil, but the increase was only $8 \%$ (Table 7).
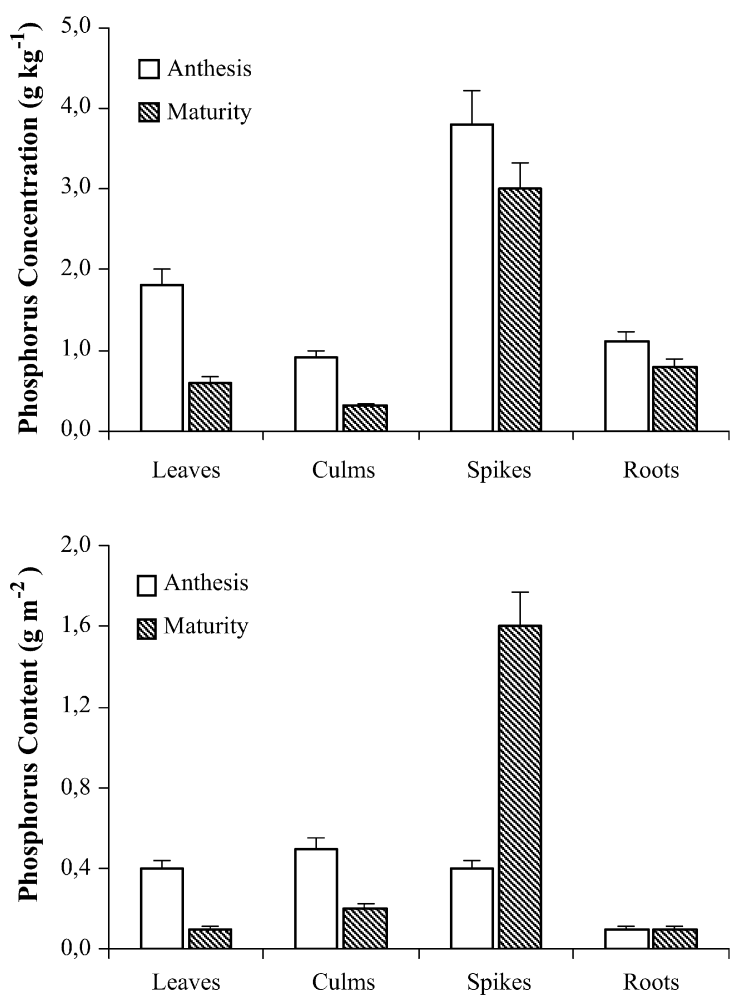

Fig. 5. Phosphorus concentration and content of leaves, culms, spikes, and roots at anthesis and at maturity.

Table 7

Post-anthesis phosphorus accumulation (PA), phosphorus remobilized into grain (PR), phosphorus remobilization efficiency (PRE) and contribution of phosphorus remobilized to phosphorus content of grain (PRC)

\begin{tabular}{lllll}
\hline Treatments & PA $\left(\mathrm{g} \mathrm{m}^{-2}\right)$ & PR $\left(\mathrm{g} \mathrm{m}^{-2}\right)$ & PRE $(\%)$ & PRC (\%) \\
\hline Variety & & & & \\
Cirillo & $0.6 \mathrm{a}$ & $0.8 \mathrm{a}$ & $61.5 \mathrm{a}$ & $57.1 \mathrm{~b}$ \\
Creso & $0.5 \mathrm{a}$ & $0.8 \mathrm{a}$ & $57.1 \mathrm{a}$ & $61.5 \mathrm{a}$ \\
Duilio & $0.5 \mathrm{a}$ & $0.9 \mathrm{a}$ & $60.0 \mathrm{a}$ & $60.0 \mathrm{a}$ \\
Grazia & $0.5 \mathrm{a}$ & $0.8 \mathrm{a}$ & $61.5 \mathrm{a}$ & $57.1 \mathrm{~b}$ \\
Soil type & & & & \\
$\quad$ Sandy-loam & $0.4 \mathrm{~b}$ & $0.5 \mathrm{~b}$ & $45.5 \mathrm{~b}$ & $55.6 \mathrm{~b}$ \\
Clay-loam & $0.7 \mathrm{a}$ & $1.2 \mathrm{a}$ & $70.6 \mathrm{a}$ & $63.2 \mathrm{a}$ \\
\hline
\end{tabular}

Variety and soil type mean values. Within treatment variety and soil type, numbers followed by the same letter are not significantly different at $P \leq 0.05$.

For all varieties grown on both soils, the remobilization of $\mathrm{P}$ was1.3-1.8 times higher than post-anthesis accumulation of $\mathrm{P}$.

\section{Discussion}

In this study, most of the dry matter, nitrogen and phosphorus retained in the wheat plant was accumulated before anthesis and significant mobilization of dry matter, $\mathrm{N}$ and $\mathrm{P}$ from vegetative plant parts to grain occurred during grain filling. However, dry matter accumulation during grain filling was much greater than dry matter remobilization, so that the contribution of remobilization to grain yield did not reach $30 \%$, while for $\mathrm{N}$ the reverse was 
true and remobilization accounted for 73 to $82 \%$ of grain $\mathrm{N}$ content. Also for $\mathrm{P}$, remobilization was greater than accumulation during grain filling, but differences among remobilization and accumulation were lower than for $\mathrm{N}$. Thus, if most of the grain carbohydrates originate from photosynthates produced during grain filling and most of the grain $\mathrm{N}$ originates from the remobilization of $\mathrm{N}$ accumulated prior to anthesis, the occurrence of photosynthesis-reducing factors during grain filling would affect carbohydrates supply to grain more than $\mathrm{N}$ supply. The maintenance of grain $\mathrm{N}$ accumulation, but a reduction in total grain carbohydrates accumulation, would explain why grain protein concentration of wheat increases with drought and is inversely related to grain yield (Frederick and Camberato, 1995; Frederick and Bauer, 1999).

The four varieties showed a similar behaviour, as they ranked in the same order for pre-anthesis and post-anthesis dry matter accumulation and grain yield, and differences in soil characteristics induced similar changes in dry matter, $\mathrm{N}$ and $\mathrm{P}$ accumulation and remobilization. This response was consistent with the results of Austin et al. (1980), Papakosta and Gagianas (1991), Nicolas and Turner (1993), who found that the genetic variation in the pre-anthesis contribution to grain yield was much less than the variation associated with the growing conditions of the crop. However, we recorded differences in grain yield among varieties, with the oldest variety, Creso, showing the lowest value and the modernest one, Grazia, the highest. The higher grain yield of Grazia was associated with a higher number of kernels per spike, which confirms the results of Slafer et al. (1993) that genetic yield gains in wheat are primarily due to an increase in the number of kernels per unit area and, since spike number has changed little, in the number of kernels per spike.

Soil type greatly affected the patterns of dry matter, $\mathrm{N}$ and $\mathrm{P}$ accumulation and remobilization. Our results indicate that plants grown on clay-loam soil had higher dry weight and $\mathrm{N}$ and $\mathrm{P}$ content both at anthesis and at maturity and higher grain yield at maturity, compared to plants grown on sandy-loam soil. The moderate growth occurred before anthesis on sandy-loam soil resulted in a low size of the sink, i.e. the spikes, and consequently, the small assimilate demand for total grain growth is greatly met by current assimilation during grain filling and low remobilization is needed. Conversely, the high dry weight of plants grown on clay-loam soil at anthesis resulted in high accumulation of assimilates available for remobilization and high assimilate demand during grain filling. Thus dry matter, $\mathrm{N}$ and $\mathrm{P}$ accumulation and remobilization were very high.

The $\mathrm{C}$ to $\mathrm{N}$ ratio (w/w) of the accumulated and remobilized materials can be estimated assuming that the carbon concentration in DM is $50 \%$. Thus, in this experiment, the $\mathrm{C} / \mathrm{N}$ ratio of the accumulated material during grain filling was 152 in sandy-loam soil and 74 in clay-loam soil, indicating a higher contribution of carbohydrates than of proteins to accumulation in the former. Conversely, the $\mathrm{C} / \mathrm{N}$ ratio of the remobilized biomass was 4.8 in sandy-loam soil and 11.3 in clay-loam soil. This indicates a higher contribution of proteins to total pre-anthesis $\mathrm{C}$ mobilization in the former. Thus, it seems that accumulation and remobilization of carbohydrates and proteins are processes that compensate each other, since grain $\mathrm{N}$ concentration did not change between soils. Obviously further investigation is needed to establish a possible cause and effect relationship.

The different $\mathrm{C} / \mathrm{N}$ ratio in mobilized biomass may indicate differences in the sources of pre-anthesis mobilization: watersoluble carbohydrates, soluble proteins, starch, organic acids, lipids and structural carbohydrates (Gebbing and Schnyder, 1999). Following Van Herwaarden et al. (1998) and Gebbing et al. (1998) the contribution of water-soluble carbohydrates, proteins and hemicellulose to remobilization differed between wheat crops grown with differential $\mathrm{N}$ fertilizer supply, indicating a different mechanism of partitioning of assimilates in the plant. However, the relative contribution of the number of compounds involved in remobilization to grain in different growing conditions is still not clear and needs further elucidation.

The remobilization phenomenon, assessed in this paper by balance sheets, is probably underestimated since respiratory costs were ignored. However, the use of ${ }^{14} \mathrm{C}$ has provided evidence that the proportion of reserves used in respiratory processes is low, indicating that respiration relies largely on current assimilation rather than on mobilized reserves (Bell and Incoll, 1990; Cruz-Aguado et al., 2000). Also N remobilization is estimated in this research by subtracting non-grain $\mathrm{N}$ at maturity from total plant $\mathrm{N}$ at anthesis. This estimate may be slightly higher than the actual remobilization, since it does not take into account the loss of $\mathrm{N}$ through volatilization.

\section{Conclusions}

Results demonstrate that there is no simple relationship between grain yield and the amount of reserves mobilized during grain filling in wheat. The four genotypes were similar for dry matter yield and for $\mathrm{N}$ and $\mathrm{P}$ uptake, and their ranking was almost the same for biomass and $\mathrm{N}$ accumulation, while for $\mathrm{P}$ accumulation no significant differences were observed. Soil type markedly affected the patterns of dry matter, $\mathrm{N}$ and $\mathrm{P}$ accumulation and remobilization, in that plants grown on clay-loam soil had higher dry weight and $\mathrm{N}$ and $\mathrm{P}$ content both at anthesis and at maturity, and higher grain yield at maturity. The moderate growth occurred before anthesis on sandy-loam soil resulted in a low source of assimilate and in a low potential sink; consequently the small assimilate demand for total grain growth is greatly met by current assimilation during grain filling. Conversely, the high dry weight of plants grown on clay-loam soil at anthesis resulted in high accumulation of assimilates available for remobilization and high assimilate demand during grain filling, so that grain yield relies on both accumulation and remobilization. The reason for the decreased dry matter production on sandy-loam soil remains unclear, but a lower supply of nutrients and water seems likely.

With the increase of plant biomass and $\mathrm{N}$ status, the amount of dry matter and nitrogen remobilized increased, and so also the $\mathrm{C}$ to $\mathrm{N}$ ratio of the remobilized material. In contrast, the $\mathrm{C}$ to $\mathrm{N}$ ratio of the assimilated material decreased where plant biomass was higher. This indicates a differential contribution of carbohydrates and proteins to accumulation and remobilization processes. The mechanism behind the use of different sources of compounds in the plant should be investigated further. 


\section{References}

Austin, R.B., Edrich, J.A., Ford, M.A., Blackwell, R.D., 1977. The fate of dry matter, carbohydrates and ${ }^{14} \mathrm{C}$ lost from the leaves and stems of wheat during grain filling. Ann. Bot. 41, 1309-1321.

Austin, R.B., Morgan, C.L., Ford, M.A., Blackwell, R.D., 1980. Contribution to grain yield from pre-anthesis assimilation in tall and dwarf barley phenotypes in two contrasting seasons. Ann. Bot. 45, 309-319.

Banziger, M., Feil, B., Stamp, P., 1994. Competition between nitrogen accumulation and grain growth for carbohydrates during grain filling of wheat. Crop Sci. 34, 440-446.

Batten, G.D., Wardlaw, I.F., Aston, M.J., 1986. Growth and the distribution of phosphorus in wheat developed under various phosphorus and temperature regimes. Aust. J. Agric. Res. 37, 459-469.

Bell, C.J., Incoll, L.D., 1990. The redistribution of assimilate in field-grown winter wheat. J. Exp. Bot. 41, 949-960.

Bidinger, F.R., Musgrave, R.B., Fisher, R.A., 1977. Contribution of stored preanthesis assimilate to grain yield in wheat and barley. Nature 270, 431433.

Blum, A., 1998. Improving wheat grain filling under stress by stem reserve mobilisation. Euphytica 100, 77-83.

Cox, M.C., Qualset, C.O., Rains, D.W., 1985. Genetic variation for nitrogen assimilation and translocation in wheat. II. Nitrogen assimilation in relation to grain yield and protein. Crop Sci. 25, 435-440.

Cruz-Aguado, J.A., Rodes, R., Perez, I.P., Dorado, M., 2000. Morphological characteristics and yield components associated with accumulation and loss of dry mass in the internodes of wheat. Field Crops Res. 66, 129139

Davidson, D.J., Chevalier, P.M., 1992. Storage and remobilization of watersoluble carbohydrates in stems of spring wheat. Crop Sci. 32, 186190

Ehdaie, B., Waines, J.G., 2001. Sowing date and nitrogen rate effects on dry matter and nitrogen partitioning in bread and durum wheat. Field Crops Res. 73, 47-61.

Frederick, J.R., Bauer, P.J., 1999. Physiological and numerical components of wheat yield. In: Satorre, E.H., Slafer, G.A. (Eds.),Physiological and numerical components of wheat yield. Wheat Ecology and Physiology of Yield Determination. The Haworth Press Inc., New York, USA, pp. 45-65.

Frederick, J.R., Camberato, J.J., 1995. Water and nitrogen effects on winter wheat in the southeastern Coastal Plain. II. Physiological responses. Agron. J. 87, 527-533.

Gallangher, J.N., Biscoe, P.V., Hunter, B., 1976. Effect of drought on grain growth. Nature 264, 541-542.

Gebbing, T., Schinyder, H., Kühbauch, W., 1998. Carbon mobilization in shoot parts and roots of wheat during grain filling: assessment by ${ }^{13} \mathrm{C} /{ }^{12} \mathrm{C}$ steadystate labelling, growth analysis and balance sheets of reserves. Plant Cell Environ. 21, 301-313.
Gebbing, T., Schnyder, H., 1999. Pre-anthesis reserve utilization for protein and carbohydrate synthesis in grains of wheat. Plant Physiol. 121, 871-878.

Gebbing, T., Schnyder, H., Kühbauch, W., 1999. The utilization of pre-anthesis reserves in grain filling of wheat. Assessment by steady-state ${ }^{13} \mathrm{CO}_{2} /{ }^{12} \mathrm{CO}_{2}$ labelling. Plant Cell Environ. 22, 851-858.

Gent, M.P.N., 1994. Photosynthate reserves during grain filling in winter wheat. Agron. J. 86, 159-167.

Kiniry, J.R., 1993. Nonstructural carbohydrates utilisation by wheat shaded during grain growth. Agron. J. 85, 844-849.

Moonen, C., Masoni, A., Ercoli, L., Mariotti, M., Bonari, E., 2001. Long-term changes in rainfall and temperature in Pisa, Italy. Agr. Med. 130, 11-22.

Nicolas, M.E., Turner, M.C., 1993. The use of chemical dessiccants and senescing agents to select wheat lines maintaining stable grain size during postanthesis drought. Field Crops Res. 31, 155-171.

Palta, J.A., Kobalta, T., Turner, N.C., Filllery, I.L., 1994. Remobilization of carbon and nitrogen in wheat as influenced by post-anthesis water deficit. Crop Sci. 34, 118-124.

Papakosta, D.K., 1994. Phosphorus accumulation and translocation in wheat as affected by cultivar and nitrogen fertilization. J. Agron. Crop Sci. 173, 260-270.

Papakosta, D.K., Gagianas, A.A., 1991. Nitrogen and dry matter accumulation, remobilization, and losses for Mediterranean wheat during grain filling. Agron. J. 83, 864-870.

Przulj, N., Momcilovic, V., 2001. Genetic variation for dry matter and nitrogen accumulation and translocation in two-rowed spring barley I. Dry matter translocation. Eur. J. Agron. 15, 241-254.

Santiveri, F., Royo, C., Romagosa, I., 2004. Growth and yield responses of spring and winter triticale cultivated under Mediterranean conditions. Eur. J. Agron. 20, 281-292.

Schnyder, H., 1993. The role of carbohydrate storage and redistribution in the source-sink relations of wheat and barley during grain filling-a review. New Phytol. 123, 233-245.

Slafer, G.A., Andrade, F.H., Satorre, E.H., 1993. Increases in grain yield in bread wheat from breeding and associated physiological changes. In: Slafer, G.A (Ed.),Increases in grain yield in bread wheat from breeding and associated physiological changes. Genetic Improvement of Field Crops. Marcel Dekker Inc., New York, USA, pp. 1-68.

Steel, R.G.D., Torrie, J.H., 1980. Principles and Procedures of Statistics, 2nd ed. McGraw-Hill, New York.

Van Herwaarden, A.F., Angus, J.F., Richards, R.A., Farquhar, G.D., 1998. 'Haying-off', the negative grain yield response of dry-land wheat to nitrogen fertiliser. II. Carbohydrate and protein dynamics. Aust. J. Agric. Res. 49, 1083-1093.

Van Sanford, D.A., MacKown, C.T., 1987. Cultivar differences in nitrogen remobilization during grain fill in soft red winter wheat. Crop Sci. 27, 295-300.

Zadoks, J.C., Chang, T.T., Konzak, C.F., 1974. A decimal code for the growth stages of cereals. Weed Res. 14, 415-421. 